\title{
Sosyal Bilgiler Öğretmen Adaylarının Eleştirel Düşünme Düzeylerinin Gelişiminde Tartışmalı Konuların Etkisi*
}

\section{The Effect of Controversial Issues on the Development of Social Studies Teacher Candidates' Critical Thinking Levels}

\author{
Ahmet Galip Yücel, ${ }^{a^{* *}}$ Mehmet Köçer ${ }^{\mathrm{b}}$ \\ ${ }^{a}$ Arş. Gör., Nevşehir Hacı Bektaş Veli Üniversitesi, Eğitim Fakültesi, Sosyal Bilgiler Eğitimi Anabilim Dalı, 50100, Nevşehir/Türkiye. \\ ORCID: 0000-0001-9435-7315 \\ ${ }^{\text {b }}$ Prof. Dr., Nevşehir Hacı Bektaş Veli Üniversitesi, Eğitim Fakültesi, Sosyal Bilgiler Eğitimi Anabilim Dalı, 50100, Nevşehir/Türkiye. \\ ORCID: 0000-0003-2794-7483
}

\section{MAKALE BİLGİSİ}

\section{Makale Geçmişi:}

Başvuru tarihi: 08 Ekim 2018

Düzeltme tarihi: 13 Kasım 2018

Kabul tarihi: 28 Kasım 2018

Anahtar Kelimeler:

Eleştirel Düşünme

Eleştirel Düşünme Öğretimi

Tartışmalı Konular

\section{ÖZ}

Öğrenciyi derslerde eleştirel düşünmenin çeşitli boyutlarıyla karşılaştırmanın, onlara nitelikli düşünme eğitimi sağlamanın bir yolu tartışmalı konulara derslerde yer verilmesidir. Bu bağlamda araştırmada, eleştirel düşünme modeli aracılığıyla tartışmalı konulara derslerde yer verilmesinin sosyal bilgiler öğretmen adaylarının eleştirel düşünme düzeylerine etkisini incelemek amaçlanmıştır. Çalışma, kontrol gruplu ön test son test yarı deneysel desene uygun olarak yürütülmüştür. Araştırmada gruplar, sosyal bilgiler öğretmen adaylarından oluşturulmuştur. Öğretmen adaylarının, bir sorun karşısındaki düşünceleri yazılı olarak alınmış ve veriler toplanmıștır. Cevaplar Bütüncül Eleştirel Düşünme Dereceli Puanlama Anahtarı ile puanlanmıștır. Verilerin analizinde istatistiksel analizler kullanılmıştır. Eleştirel düşünme modeli ile tartışmalı konuların derslerde ele alınmasının eleștirel düșünme düzeylerine anlamlı derecede ve olumlu yönde etki ettiği anlaşılmıştır. Ayrıca öğretmen adaylarının, eleştirel düşünmeye yönelik düşünme öğretimine ihtiyaç duydukları sonucuna ulaşılmıştır.

\section{A B S T R A C T}

One way for the student to confront with the various dimensions of critical thinking in the lessons and to provide them quality thinking training is to give place to controversial topics in the lessons. In this context, in the research it is aimed to investigate the effect of giving lectures on controversial topics, through the critical thinking model, on social studies teacher candidates' critical thinking levels. The study was conducted in accordance with the comparison group pretest - posttest quasi-experimental design. In the study, the groups were composed of social studies teacher candidates. The opinions of teacher candidates toward a problem were taken in writing and data were collected. The answers were scored through Holistic Critical Thinking Scoring Rubric. In the data analysis section, statistical analyzes were used. As a result of the research, it has been understood that the giving place to the controversial topics in the lesson with a critical thinking model has a significant and positive effect on the teacher candidates' critical thinking levels. In the research it is reached the conclusion that the teacher candidates, need critical thinking instruction.

\section{Giriș}

Sosyal bilgiler dersi, programda yer alan becerileri öğrencilere kazandırarak demokratik ve etkin vatandaşlar yetiştirmeyi amaçlar. Bu beceriler arasında yer alan eleştirel düşünme hayatın her alanını etkileyen oldukça karmaşık bir özelliktir. $\mathrm{Bu}$ nedenle öğrencilerin yeterli düzeylerde eleştirel düşünebilmeleri, tesadüfî gelişimler göz ardı edildiği takdirde, eğitim almalarını bağlıdır. Bu durum ise öğretmenlerin eleştirel düşünme yetkinliklerini, sosyal bilgiler programının amaçlarına ulaşabilmesi bakımından önemli hale getirir. Farklı eğitim kademelerindeki

*Bu çalışma, Ahmet Galip Yücel tarafından 2018 yılında Nevşehir Hacı bektaş-1 Veli Üniversitesi Sosyal Bilimler Enstitüsü Sosyal Bilgiler Eğitimi Anabilim Dalı'nda Prof. Dr. Mehmet Köçer danışmanlığında hazırlanan "Sosyal Bilgiler Öğretmen Adaylarının Eleştirel Düşünme Düzeylerinin Gelişiminde Tartışmalı Konuların Etkisi”" adlıyüksek lisans tezinden üretilmiştir.

** Sorumlu yazar/Corresponding author

e-posta: ahmetyucel@gmail.com 
öğrencileri eleştirel düşünme bakımından inceleyen araştırmalar, istenen noktaya gelinemediğini öne sürmektedir (Acun, Demir ve Göz, 2010; Akar, 2007; Bessick, 2008; Gülveren, 2007; İbrahimoğlu ve Öztürk, 2013; Öztürk ve Ulusoy, 2008). Bu bağlamda mevcut öğretim yaklaşımlarının, eleştirel düşünme bakımından gözden geçirilmesinin gerektiği düşünülmektedir.

Paul ve Elder (2002), insanların doğaları gereği düşündüklerini fakat bu düşüncelerin çoğunlukla rastgele, taraflı, çarpıtılmış, yetersiz, bilgiye dayanmayan ya da düpedüz önyargılı olduğunu ileri sürmektedir. Bugün insanlar kişisel yaşamlarında meslek seçimi, eş tercihi, para yönetimi, eğitim gibi birçok farklı alanda bireysel kararlar almak zorunda kalırken, demokratik katılımın bir gereği olarak ise toplumun geleceğinde hayati işlevler üstlenmektedir. Bu sebeplerle rastgele, taraflı, çarpıtılmış, yetersiz, bilgiye dayanmayan ya da önyargılı düşünceler, verilen kararların kalitesini düşürmektedir.

Bugünün modern toplumunda öğrencilerin potansiyellerinin üst sınırlarına ulaşabilmeleri, düșünme ve akıl yürütme becerilerini öğrenmelerine bağlıdır (Baker, Rudd ve Pomeroy, 2001). Bilgi bombardımanı nedeniyle ilgili, güvenilir bilgiler seçilmeli, yorumlanmalı, hazmedilmeli, değerlendirilmeli, bilgiyi değerlendirme yolları öğrenilmeli ve uygulanmalıdır çünkü bilgi, artık bir insandan diğerine aktarılan statik bir haber ya da duyum değildir, dinamiktir ve kişinin kendince yorumlaması, anlaması ve anlamlandırması ile oluşturulur (Halpern, 2002). Facione ve Facione (1996)'a göre eleştirel düşünme; yorumlama, analiz, değerlendirme ve çıkarımda bulunma ile sonuçlanan, amaca dönük, öz düzenlemeli bir karar verme sürecidir. Bu karar verme aynı zamanda, kavramsal, metodolojik, ölçüt temelli ve bağlamsal düşüncelerin ve kanıtların izahına dayalıdır (Facione ve Facione, 1996). Ennis (1985)'e göre iseeleştirel düşünme, neye inanılacağına ya da ne yapılacağına karar vermeye odaklanan mantıklı ve yansıtıcı düşünmedir.

Günümüz dünyasında bireyler onlarca kaynaktan gelen, çok sayıda bilgiyi değerlendirmek zorunda kalmaktadır. Bu bilgilerin büyük bir kısmı ise kişileri, bilgi kaynağının belirlediği düşüncelere yönlendirme amacı gütmektedir. $\mathrm{Bu}$ noktada eleştirel düşünme propagandaya ve akıl kontrolü çabalarına yönelik bir savunma mekanizması olarak değerlendirilebilir (Halpern, 2002; İbrahimoğlu ve Öztürk, 2013). Eleştirel düşünme, çok fazla bilgi içeren bir dünyaya ve bizi ikna etmeye çalışan çok sayıda insana karşı bir savunmadır (Epstein ve Kernberger, 2006) ve temel olarak sorgulamaya dayalı beceriler gerektiren bir düşünme türüdür (Kurt ve Kürüm, 2010). Bu kapsamda doğru kararlar verebilmek ve olgu ya da durum karşısında doğru konum alabilmek için eleştirel düşünebilmek gerekir. Eleştirel düşünmek işinin kendisinin ve diğerlerinin görüşlerini ölçütlere göre değerlendirmesini kapsar (Norris, 1985). Söz konusu ölçütlere dayalı değerlendirme verilecek kararların niteliğini arttıracaktır.

Beceriler ve eğilimler olmak üzere iki temel unsuru bulunan eleştirel düşünmenin hayata aktarılmasında üst düzey bilişsel becerilere sahip olmak tek başına yeterli olmamaktadır. Bireyin eleştirel düşünmeye eğilimli olması bu becerilerin kullanılmasında kilit rol üstlenmektedir. Facione (2000)'e göre, eleştirel düşünme becerileri, düşünmeye yönelik tutarlı bir iç motivasyonla pozitif yönde ilişkilidir ve belirli eleştirel düşünme becerileri belirli eleştirel düşünme eğilimleriyle eşleşmektedir. 1990 yılında Amerikan Felsefe Derneği (The American Philosophical Association) eleştirel düşünme ve bağlı konuları üzerine uzlaşı oluşturmak üzere yaptığı çalışmaların sonuçlarını raporlaştırmıştır. $\mathrm{Bu}$ metin, Delphi raporu olarak bilinmektedir. Söz konusu raporda temel eleştirel düşünme becerileri olarak "yorumlama, analiz etme, çıkarımda bulunma, değerlendirme, açıklama ve öz düzenleme" sıralanmıştır (Facione, 2015). Eleştirel olmaya hevesli olma hali eleştirel düşünme becerileri kadar önemlidir (Norris, 1985). Çünkü eleştirel düşünmeye hevesli olma hali olarak ifade edilebilecek eğilimler, becerileri harekete geçiren tetikleyicilerdir. Facione ve Facione (1996)'a göre eleştirel düşünmeyi harekete geçiren eğilimler gerçeğin peşinde olmak, açık fikirlilik, analitiklik, sistematiklik, eleştirel düşünmeye yönelik kendine güven, meraklılık ve olgunluktur.

Öğrenciler; düşüncelerini değerlendirmek ve özellikle davranışlarını, eleştirel düşünmenin bir sonucu olarak değiştirmek için mevcut bildiklerini nasıl kullanacaklarını öğrenmelidir (Norris, 1985). Değişimin hızlanması, karmaşıklığın artması ve tehlikelerin yoğunlaşması geleneksel öğrenme yöntemleri için ölüm çanlarının çaldığını göstermektedir (Paul ve Elder, 2002). Geleneksel yöntemlerin öğrencileri istenilen düzeyde bilişsel olgunluğa taşıyamadığı, eğitim araştırmacıları tarafından sıklıkla tekrarlanan bir savdır. Bu bağlamda eleştirel düşünebilmek ve bilişsel olgunluğa erişmek, birey ve içinde yaşadığı toplum için önemlidir. Facione, Sanchez, Facione ve Gainen (1995)'e göre, bilişsel olgunluk ve eleştirel düşünmeye duyulan güven kişiyi daha sofistike çıkarımlara ve mantıklı açıklamalara götürebilir. $\mathrm{Bu}$ nedenle, erken çocukluk çağında eleştirel düşünme eğitiminin verilmesinin, ileride bir dirençle karşılaşılmaması açısından önemli olduğu (Durr, Lahart ve Maas, 1999) dikkate alınarak, eleştirel düşünmeye yönelik eğitim süreçlerinin tasarlanması bir zorunluluktur. Bilişsel becerilerin, özel olarak tasarlanmış öğretim yoluyla öğrenilebileceği ve bu becerilerin çoklu bağlamlarda çalışıldığı takdirde gerçek dünyada karşılaşılabilecek durumlara uygulanabileceği yönünde çeşitli deneysel kanıtlar bulunmaktadır (Halpern, 2002).Demokratik değerlere ve becerilere sahip vatandaşlar yetiştirmek sosyal bilgilerin öncelikli amaçlarından birisidir. Anayasal demokrasilerde, vatandaşların çoğunluk kurallarını anlamaları ve bunlara katılmaları, azınlık haklarına saygı duymaları, ortak faydayı gözetmeleri, birbirlerinin özgürlüklerini korumaları ve hükümetin boyutunu ve erişimini sınırlandırmaları konusunda eğitim almaları gerektiği yönünde genel bir görüş birliği bulunduğunu ifade eden Parker (2012) demokrasi eğitimine işaret etmektedir. Avaroğulları (2015), demokratik vatandaş olmanın gereklerini; işbirliği yapma, sosyal adaleti benimseme, eleştirel düşünebilme, sorunlarda çözümünde şiddetten kaçınma, insan haklarını savunma ve demokratik siyasete katılma olarak sıralamış ve üzerinde anlaşmazlık olan konuların demokratik bir şekilde tartışılması gerekliliğini demokratik vatandaşlık eğitimin kaçınılmaz bir sonucu olduğunu belirtmiştir.

Demokrasi çözülmeyi bekleyen sorunlarla doludur. Bu nedenle öğretmenler çocukları sürekli olarak küçük 
sorunları işbirliği içinde çözmeye cesaretlendirmelidir (Parker, 2012), çünkü vatandaşlara yönelik beklentilerden biri dünyada ve toplumda üzerinde uzlaşılamayan konuların farkında olmaları ve bu konuların çözümlerine yönelik öneriler sunmalarıdır (Ersoy, 2013). Öğrenciler demokrasiyi yaşamak ve sosyal sorunları çözmek için eğitim görmedikleri takdirde, topluma karşı ilgisiz olabilirler. Eğitimde demokratik unsurlar göz ard1 edildiğinde, istenen akademik hedeflere ulaşılsa dahi, yıkıcı sonuçlarla karşılaşmak olasıdır. Parker (2012) bu durumu 2. Dünya Savaşı Almanya'sı ile örneklendirmektedir. İkinci Dünya Savaşı Almanya'sında insanlığa karşı suçlara bulaşan kişiler, iyi eğitilmiş, matematik, fen, edebiyat, bilim, sanat ve mimaride üstün becerilere sahip insanlardı (Parker, 2012). Bu nedenle eğitimde demokrasi vurgusu yapabilecek yöntem ve teknikleri belirleyerek uygulamak bir tercih meselesinden ziyade zorunluluktur. Geleneksel yöntemler içerik odaklıdır ve içerikten çok daha önemli olan öğrenme süreçlerini göz ardı eder (Suryanto, 2015). Öğrenme süreçlerini dikkate alan ve öğrenciyi öğrenme süreçlerinin merkezine konumlandıran yöntem ve teknikler demokrasinin sürdürülebilir olmasına yardımcı olur. $\mathrm{Bu}$ amaca yönelik mevcut bir öğretim yöntemi sınıf tartışmalarıdır (Byford, Lennon ve Russell, 2009). Bu nedenle tartışmalı konuların eleştirel düşünmeye olumlu katkılar sağlaması muhtemeldir.

Çeşitli öğretim kademelerinde öğrenim gören öğrencilerin eleştirel düşünme düzeylerini ele alan birçok araştırma, eleştirel düşünmenin yeterli düzeyde olmadığına işaret etmektedir (Acun, Demir ve Göz, 2010; Akar, 2007; Bessick, 2008; Gülveren, 2007; İbrahimoğlu ve Öztürk, 2013; Öztürk ve Ulusoy, 2008). Söz konusu çalışmaların sonuçları göz önünde bulundurularak sosyal bilgiler öğretmen adaylarının eleştirel düşünme becerilerini geliştirebilecek uygulamalar çalışılmaya değer bulunmuştur. Araştırmada; Türkiye Cumhuriyeti Tarihi - I dersi içeriğine eklenen tartışmalı konular ile konu temelli eleştirel düşünme öğretiminin, sosyal bilgiler öğretmen adaylarının eleştirel düşünme düzeylerine etkisinin incelenmesi amaçlanmıştır. Bu kapsamda aşağıdaki ifadeler araştırma problemleri olarak belirlenmiştir.

1- "Çalışma grubunda yer alan öğretmen adayları ne düzeyde eleştirel düşünmektedir?"

2- “Tartışmalı konulara dayalı olarak hazırlanan ders içeriğinin sosyal bilgiler öğretmen adaylarının eleştirel düşünme düzeylerine etkisi nedir?"

\section{Yöntem}

$\mathrm{Bu}$ bölümde; çalışmanın modelinden, çalışma grubundan, veri toplama aracindan, verilerin toplanmasından, verilerin analizinden ve işlem sürecinden bahsedilmektedir.

\subsection{Araştırma Modeli}

Sosyal bilgiler öğretmen adaylarının eleştirel düşünme düzeylerini belirleyerek tartışmalı konulara derslerde yer verilmesinin eleştirel düşünme üzerindeki etkisini tespit etmeyi amaçlayan bu çalışma, yarı deneysel yöntemlerden, kontrol gruplu ön test - son test desenine uygun olarak tasarlanmış ve yürütülmüştür. Araştırmada kullanılacak deneysel desenin seçiminde, eğitim ortamlarının deney ve kontrol gruplarına rastgele atama yapmaya müsait olmaması etkili olmuştur.

Deneysel desenlerde amaç, bir işlemin ölçülebilen sonuçlar üzerinde etkili olup olmadığını belirlemektir (Creswell, 2013). Bu amaçla iki farklı işlemin sonuç üzerindeki etkileri karşılaştırılır. $\mathrm{Bu}$ desene göre tasarlanan araştırmalarda etkililiği denetlenecek işlem dışındaki tüm değişkenler kontrol altına alınmaya çalışılır (Büyüköztürk, Kılıç Çakmak, Akgün, Karadeniz ve Demirel, 2012). Müdahale süreci sonunda iki farklı işlemin uygulandığı farklı grupların puanları değerlendirilir (Creswell, 2013). $\mathrm{Bu}$ araştırmanın deneysel müdahale süreci 7 hafta olarak tasarlanmıştır. Deneysel sürecin öncesinde eleştirel düşünme ve eleştirel düşünme öğretiminde kullanılacak modele yönelik eğitim çalışmaları yapılmış, devamında deneysel işlem uygulanmış, sonrasında ise farklı işlemler uygulanan grupların puanları değerlendirilmiştir.

\section{2. Çalışma Grubu}

Kontrol gruplu ön test - son test desenine uygun olarak, çalışmada bir kontrol ve bir deney grubu belirlenmiştir. Deney ve kontrol grubu rastgele atama yapılmaksızın seçilmiştir. Çalışmanın deney grubu Nevşehir Hacı Bektaş Veli Üniversitesi, Eğitim Fakültesi, Sosyal Bilgiler Eğitimi Anabilim dalında 4. sınıfta öğrenim gören 31 öğrenciden oluşturulmuştur. Kontrol grubunda ise Niğde Ömer Halisdemir Üniversitesi, Eğitim Fakültesi, Sosyal Bilgiler Eğitimi Anabilim dalında 4. sınıfta öğrenim gören 32 öğretmen adayı yer almıştır. Çalışma grubunda yer alan öğretmen adaylarının cinsiyetlere göre dağılımını gösteren tablo aşağıda verilmiştir.

Tablo 1.Katılımcı grubunun cinsiyete göre dağılımı

\begin{tabular}{llll}
\hline Grup & Kadın & Erkek & $\begin{array}{l}\text { Toplam } \\
\text { Katılımc1 }\end{array}$ \\
\hline Deney & 22 & 9 & 31 \\
Kontrol & 16 & 16 & 32 \\
Toplam & 38 & 25 & 63 \\
\hline
\end{tabular}

\subsection{Veri Toplama Arac1}

Araştırmada katılımcıların ön test ve son test eleştirel düşünme düzeylerinin hesaplanabilmesi için Facione ve Facione (1994) tarafından geliştirilen "Bütüncül Eleştirel Düşünme Dereceli Puanlama Anahtarı (BEDDPA)" kullanılmıştır. Veri toplama aracının dili İngilizce olduğundan önce çevirisi yapılmış, alan ve dil uzmanlarına sunulmuştur. Üç alan uzmanı, üç Türkçe ve üç İngilizce uzmanı tarafından veri toplama aracının Türkçe formunun aslına uygun olduğu teyit edilmiştir.

Facione ve Facione tarafindan (1994), dört düzeyli bir rubrik olarak geliştirilen veri toplama aracında eleştirel düşünme açısından; birinci düzey zayıf, ikinci düzey kabul edilemez, üçüncü düzey kabul edilebilir ve dördüncü düzey güçlü olarak nitelendirilmiştir. BEDDPA eleştirel düşünmeyi belirli eğilimlerce desteklenen üst düzey bilişsel beceriler olarak kabul etmektedir. Facione ve Facione (1994)'a göre BEDDPA makale ve kompozisyon gibi yazılı 
metinlerin eleştirel düşünme açısından incelenmesi konusunda etkilidir. Araştırma sürecinde öğretmen adaylarının ön test ve son test aşamalarında yazılı olarak görüşleri alınacağından söz konusu veri toplama aracının araştırma amacına uygun olduğu değerlendirilmiş ve veri toplama sürecinde tercih edilmiştir.

BEDDPA kullanılarak yapılacak bir değerlendirmenin en az iki kişi ile yapılması gerekmektedir. Olası puanlama uyuşmazlıklarında iki puanlayıcı arası tartışma, üçüncü bir puanlayıcıya puanlatma ya da puanların ortalamasını alma yollarından biri izlenmelidir. Bu bağlamda veri toplama aracının kullanım ilkelerine uygun olarak analiz sürecinde oluşan puanlayıcı uyuşmazlıklarında, iki puanlayıcının tartışarak ortak karara dayalı bir puan belirlemeleri yoluna gidilmiştir.

BEDDPA düzeyler arasında zorunlu bir seçim yapmayı gerektiren ve yarım puana müsaade etmeyen bir dereceli puanlama anahtarıdır. Birinci (zayıf) ve ikinci (kabul edilemez) düzeyler bir araya getirilerek üç düzeyli bir yapı olarak da kullanılabilen puanlama anahtarında zorunlu olarak her bir katılımcı için düzeylerden biri seçilmelidir (Facione ve Facione, 1994).

\subsection{Verilerin Toplanmas 1}

Araştırmanın deneysel müdahale sürecinin öncesinde ve sonrasında, öğretmen adaylarının bilgi sahibi oldukları bir konuda düşüncelerini yazılı bir şekilde alarak veri toplama aracı ile eleştirel düşünme düzeylerini belirlemek amaçlanmıştır. Sorunun belirlenmesinde konunun güncelliğini koruyan bir meseleye dönük olması, eleştirel düşünmenin açığa çıkarılmasına elverişli olması ve öğretmen adaylarının konuya yabancı olmamaları dikkate alınmıştır. Bu bağlamda ön test ve son test aşamalarında, öğrencilere güncel bir tartışmalı konuya dayalı bir soru yöneltilerek öğretmen adaylarının ayrıntılı olarak yazılı cevapları alınmıştır. Söz konusu cevaplar BEDDPA aracılığı ile puanlanarak istatistiksel olarak incelenebilecek araştırma verileri elde edilmiştir.

\subsection{Verilerin Analizi}

Toplanan veriler BEDDPA aracılığı ile puanlanarak istatistiksel analizlere tabi tutulmuştur. Veri analizinin tüm aşamalarında istatistiksel anlamlılık düzeyi " 0,05 " olarak kabul edilmiştir. Araştırmada öğretmen adaylarının eleştirel düşünme puanlarının normal bir dağılım gösterip göstermediğini anlamak üzere veri setine normallik testi uygulanmıştır. Kontrol ve deney gruplarında katılımc1 sayıları 50'nin altında olduğundan Shapiro Wilk testine başvurulmuştur. Test sonuçları aşağıda tablo halinde sunulmuştur.

Tablo 2. Normallik testi sonuçları

\begin{tabular}{llcc}
\hline \multirow{2}{*}{ Grup } & Test & \multicolumn{2}{c}{ Shapiro Wilk } \\
\cline { 3 - 4 } & & $\mathbf{N}$ & $\mathbf{p}$ \\
\hline \multirow{2}{*}{ Deney Grubu } & Ön Test & 31 & 0,002 \\
& Son Test & 31 & 0,002
\end{tabular}

\begin{tabular}{lccc}
$\begin{array}{l}\text { Kontrol } \\
\text { Grubu }\end{array}$ & Ön Test & 32 & 0,000 \\
& Son Test & 32 & 0,000 \\
\hline
\end{tabular}

Test sonuçlarında her iki grubun ön test ve son test Shapiro Wilk değerlerinin 0,05 değerinden küçük olması ile verilerin normal dağılım göstermediği düşünülerek analiz aşamasında non parametrik testler kullanılmıştır.

Deney ve kontrol gruplarında yer alan öğretmen adaylarının süreç içindeki eleştirel düşünme düzeylerindeki değişimlerin anlamlı düzeyde olup olmadığını anlamak üzere Wilcoxon testi gerçekleştirilmiştir. Deney grubunun puanlarını, kontrol grubunun puanları ile karşılaştırmak üzere ise Mann Whitney U testi uygulanmıştır. İki değer alabilen değişkenlerin eleştirel düşünme üzerindeki etkisini incelemek için Mann Whitney U testleri kullanılmıştır.

\subsection{Deneysel İşlem}

\subsubsection{Uygulama Öncesi Hazırlıklar}

1. Deneysel süreç içerisinde yapılacaklar, izlenecek ders planları ve eleştirel düşünme öğretimine yönelik bilgiler ön test sonrasındaki derste ögrencilere tanıtılmış ve temel noktalar hakkında gerekli eğitim öğrencilere verilmiştir.

2. Tartışmalı konulara derste yer verilmesi ile elde edilebilecek katkıyı en üst seviyeye çekebileceği düşünülen eleştirel düşünme modeline ilişkin tanıtıcı verileri ve örnek bir düşünme yapısını içeren bir belge çıktısı ihtiyaç duyduklarında kullanmaları için öğrencilere dağıtılmıştır.

3. Öğretmen adayları ile sınıflarında görüşmeler gerçekleştirilmiş, öğrenci seviyesine ve ilgisine uygun olacağı düşünülen tartışmalı konular, öğretmen adaylarının görüşleri de dikkate alınarak belirlenmiştir. $\mathrm{Bu}$ kapsamda ders programına ve haftalık ders planlarına uygun olarak Sevr Antlaşması, Lozan Antlaşması, demokratik otoriter yönetimler, Atatürk ilkeleri, ekonomik sistemler ve Milli Mücadele dönemi isyanlarının günümüze yansımaları konularına derslerde yer verilmesine karar verilmiştir. $\mathrm{Bu}$ kapsamda araştırmacı, her hafta konuya uygun tartışmalı konuyu da içerecek şekilde bir ders planı hazırlamıştır. Ders planlarının hazırlanmasında ders amaçları ile öğrenme çıktıları göz önünde bulundurulmuştur. Dersler Paul (Paul ve Elder, 2002) tarafindan geliştirilen eleştirel düşünme modeline uygun olarak yürütülmüştür.

4. Tartışmalı konuların ele alınması sürecinde karşılaşabilecek zorlukları minimum düzeye indirebilmek için deneysel işlem öncesinde katılımcılarla beraber tartışma kuralları belirlenmiştir. Bu kapsamda; iddiaların kanıt ve argümanlarla desteklenmesi, düşüncesini beyan eden kişinin değil, düşüncenin tartışılması, konuşmalarda akademik ve bilimsel dile uygun ifadelerin kullanılmasına gayret gösterilmesi, hakaret ya da rencide edici sözlere ifadelerde yer 
verilmemesi, konuşan kişilerin sözlerini bitirmelerinin beklenmesi ve devletin koyduğu yasal sınırların dışına çıkılmaması genel tartışma kuralları olarak belirlenmiştir.

5. Eleştirel düşünme becerilerinin en azından temel bilgi düzeyi gerektirmesi karşısında, bir sonraki dersin içeriğinin ve ele alınacak tartışmalı konunun bir önceki derste öğretmen adaylarına bildirilmesine karar verilmiştir. Öğretmen adaylarından verilen konu hakkında temel bilgileri öğrenmeleri ve konu üzerinde eleştirel düşünme modeline uygun bir şekilde düşünmeleri istenmiştir. Bu sayede öğretmen adaylarının derse eklenen tartışmalı konu hakkında bilgi sahibi olmalarına olanak sağlamak amaçlanmıştır.

6. Tartışmalı konuların ele alınmasında kullanılacak eleştirel düşünme modeli uygulama başlamadan önce öğretmen adaylarına tanıtılmış, bu modele yönelik öğretim yapılmış ve modelin anlaşılması için modele uygun düşünmelere yönelik örnekler uygulama öncesinde sinıfta tartışılmıştır. Ayrıca modelin unsur ve standartlarını içeren bir model kılavuzu ile modele uygun olarak tasarlanmış bir örnek çıktısı ihtiyaçları halinde kullanmaları için öğretmen adaylarına dağıtılmıştır.

\subsubsection{Uygulama Süreci}

1. Deneysel süreçte araştırmac1, öğretmen adaylarının fikirlerini özgürce ifade edebilmelerine olanak sağlamak ve tartışma ortamı oluşturabilmek adına tartışmanın eşit bir katılımcısı gibi hareket etmeyi tercih etmiştir. Eleştirel düşünmeye olanak sağlayabilecek iyi fırsatlar ve tartışmanın tıkandığı zamanlar bu durumun istisnaları olarak belirlenmiştir. Böylesi durumlarda araştırmacı zaman zaman katılımcılarla aynı düşüncede olmasına rağmen zıt düşünceleri savunmuş, aykırı sorular sormaya çaba göstererek, öğrencileri faydalı bir gerilim içerisine sokma girişimlerinde bulunmuş ve konuların farklı boyutlarını işaret etmiştir. Araştırmacı böyle anlarda tartışmayı derinleştirmeyi ve Browne ve Freeman (2000)'in eleştirel düşünmeye olanak sağladığını ifade ettikleri gelişimsel gerilimden faydalanmayı amaçlamıştır.

2. Deneysel süreçte yürütülen her dersin ilk aşamasında araştırmacı konuya tartışma, soru cevap, düz anlatım gibi yöntemlerle giriş yaptıktan sonra, konu açısından önemli temel noktaları vurgulamış ve konunun derse entegre edilen tartışmalı konu ile ilişkisini kurmuştur. $\mathrm{Bu}$ aşamadan sonra araştırmacı belirlenen tartışma kurallarına, eleştirel düşünme modeline veya sınıf düzenine aykırı davranışların gösterildiği anlar ile öğretmen adaylarının konularla ilgili ek bilgiye ihtiyaç duydukları anlar dışında tartışmalı konuların konuşulmasına müdahale etmemiştir. Tartışmalı konunun ele alınması sırasında öğretmen adaylarının bilgi eksikliği nedeniyle bariz hatalı sonuçlara yöneldikleri noktalarda araştırmacı müdahale ederek ek bilgi ihtiyacını gidermeyi denemiştir.

3. Her dersin son $10-15$ dakikasında konu üzerindeki tartışmalar sonlandırılarak konunun ve tartışmanın değerlendirmesi yapılmış ve ders boyunca öğretim modeline uygun olmayan tutum ve davranışlar ele alınmıştır. Bu kapsamda araştırmacı "argüman ve kanıta dayalı olmayan iddialar, argüman ve kanıtın yanlış yorumlanması ile ortaya atılan iddialar, hatalı neden - sonuç ilişkileri, ilgisiz bilgiler ve önyargılar" gibi hatalara sebebiyet veren olgular konusunda öğretmen adaylarına açıklamalarda bulunmuştur. Böylece sınıf düzenini ve tartışma sürecini baltalayan ve eleştirel düşünmenin oluşmasına engel teşkil eden davranışları minimum düzeye çekmek için çaba sarf eden araștırmacı, eleştirel düşünmeye olanak sağlayan bir sınıf iklimi oluşturmayı amaçlamıştır.

4. Tartışmalı konuların ele alınması sırasında öğretmen adaylarından araştırmada kullanılan eleştirel düşünme modeline uygun davranmaları istenmiştir. $\mathrm{Bu}$ bağlamda öğretmen adaylarının konu hakkında düşüncelerini oluştururken eleştirel düşünmenin unsurlarına uygun davranmaları ve sonuç düşüncelerini eleştirel düşünme standartlarına göre gözden geçirmeleri istenmiştir.

\subsection{Tartışmalı Konuların Ele Alınmasında Takip Edilen Eleştirel Düşünme Modeli}

Richard Paul tarafindan geliştirilen modelde (Paul ve Elder, 2002) amaç; bireyin öncelikle akıl yürütmenin unsurlarını ve bu unsurlar gereğince sorulması gereken soruları gözeterek konu üzerinde düşünmesi ve sonrasında düşündükleri ile vardığı sonuçları eleştirel düşünme standartları kapsamında incelemesidir. Paul ve Elder'e göre akıl yürütmenin unsurları amaç, konuya ilişkin sorular, bilgiler, kavramlar, varsayımlar, bakış açıları, çıkarımlar ve sonuçlardır. Sonuç düşünce ve çıkarımların denetleneceği standartlar ise açıklık, kesinlik, hassaslık, ilgililik, derinlik, kapsamlılık, önemlilik, mantığa uygunluk ve doğruluktur.

\section{Bulgular ve Yorum}

Birinci araştırma problemine yönelik olarak, deneysel müdahaleden önce her iki gruba da ön test uygulanmış, öğretmen adaylarının eleştirel düşünme düzeyleri belirlenmiş ve Mann Whitney U testi ile karşılaştırılmıştır. $\mathrm{Bu}$ verilere ilişkin tablo aşağıda sunulmuştur. 
Tablo 3. Grupların ön test sonuçlarına ilişkin Mann Whitney U tablosu

\begin{tabular}{rccccccc}
\hline & Grup & N & S.O. & S.T. & U & z & p \\
\hline \multirow{3}{*}{ Ön test } & Deney & 31 & 32,97 & 1022,00 & & & \\
& Kontrol & 32 & 31,06 & 994,00 & 466,000 & $-0,444$ & 0,657 \\
& Toplam & 63 & & & & &
\end{tabular}

Yukarıdaki tablodan anlaşılacağı üzere deney grubu ile kontrol grubu eleştirel düşünme düzeyleri arasında, ön test aşamasında anlamlı düzeyde bir farklılık bulunmamaktadır. Deney grubu eleştirel düşünme düzey ortalamasının, kontrol grubu ortalamasina oranla biraz daha yüksek olmasına rağmen her iki grubun ön test puanları birbirine

Tablo 4. BEDDPA'ya göre katılımcı düzeyleri

\begin{tabular}{lllllll}
\hline & Grup & Zayıf & Kabul Edilemez & Kabul Edilebilir & Güçlü & N \\
\hline \multirow{2}{*}{ Ön Test } & Kontrol & 13 & 14 & 4 & 1 & 32 \\
Toplam & 12 & 12 & 5 & 2 & 31 \\
\hline
\end{tabular}

Her iki grupta yer öğretmen adaylarının eleştirel düşünme düzeyleri büyük oranda, BEDDPA düzeylerine göre kabul edilebilir sınırın altında kalmıştır. Bu bağlamda çalışma grubunda yer alan öğretmen adaylarının büyük oranda eleştirel düşünemediği bulgusuna ulaşılmıştır. çok yakındır. Bu bilgiler ışı̆̆ında araştırmacılar, eleştirel düşünme düzeyleri bakımından, grupların denk olduğu varsayımı ile çalışmayı sürdürmüşlerdir.

Çalışma grubunda yer alan öğretmen adaylarının BEDDPA düzeylerine göre dağılımlarını gösteren tablo aşağıda sunulmuştur.
İkinci araştırma problemine yönelik olarak, deneysel müdahale sonrasında son test uygulanarak çalışma gruplarının eleştirel düşünme düzeyleri belirlenmiştir. Deney grubunun ön test ve son test puanlarındaki değişimi belirlemeye yönelik olarak gerçekleştirilen Wilcoxon testi sonuçları aşağıdaki tabloda sunulmuştur.

Tablo 5. Deney grubunun ön test - son test puanlarının karşılaştırılmasına ilişkin Wilcoxon testi sonuçları

\begin{tabular}{|c|c|c|c|c|c|}
\hline Puan & Siralar & $\mathbf{N}$ & S. O. & $\mathbf{z}$ & $\mathbf{p}$ \\
\hline \multirow{4}{*}{$\begin{array}{l}\text { Son test puanlar1- } \\
\text { Ön test puanları }\end{array}$} & Negatif Sıralar & 4 & 10,50 & $-2,481^{*}$ & 0,013 \\
\hline & Pozitif Siralar & 16 & 10,50 & & \\
\hline & Eşit & 11 & & & \\
\hline & Toplam & 31 & & & \\
\hline
\end{tabular}

* Negatif siralara dayalı

Tablodan anlaşılacağı üzere uygulama sonrasında, deney grubunda yer alan öğretmen adaylarının son testten aldıkları puan ile ön test puanları arasında istatistiksel açıdan anlamlı bir farklılık tespit edilmiştir (z:-2,481, p<0,05). Söz konusu

\section{Sonuç, Tartışma ve Öneriler}

\subsection{Tartışma}

Çalışmadan elde edilen bulgular deney ve kontrol gruplarında yer alan öğretmen adaylarının eleştirel düşünme düzeylerinin ön test safhasında düşük kabul edilen sınırlarda bulunduğunu göstermektedir $(\mathrm{x}=1,90, \mathrm{x}=1,78)$. Alanyazında her seviyeden öğretim kademelerindeki öğrencilere yönelik yapılan çalışmalar, eleştirel düşünme düzeylerinin genel anlamda yetersiz ve düşük düzeyde olduğunu belirtmektedir (Acun vd., 2010; Akar, 2007; farklılık son test puanı lehinedir. Bu bağlamda uygulama sürecinde izlenen tartışmalı konulara dayalı yöntemin öğrencilerin eleştirel düşünme düzeylerine olumlu yönde ve anlamlı düzeyde etki ettiği bulgusuna ulaşılmıştır.

Gülveren, 2007; Bessick, 2008; İbrahimoğlu ve Öztürk, 2013; Öztürk ve Ulusoy, 2008). Bu anlamda çalışmanın sonuçları literatürdeki çalışmaların büyük bir bölümü ile paraleldir. Rekabete dayalı bir dünyada eleştirel düşünmenin fark yaratacağı açıktır. Türkiye'de kısa bir süre sonra sosyal bilgiler öğretmenliği yapması muhtemel öğretmen adaylarının eleştirel düşünme düzeyleri bu araştırma özelinde yetersiz bulunmuştur. Eleştirel düşünme becerilerine sahip olmayan öğretmenlerin, öğrencilerinin eleştirel düşünmelerine katkı sağlayacaklarını düşünmek dayanaklı bir yaklaşım olmayacaktır. Söz konusu öğretmen adaylarının sosyal bilgiler öğretmenleri olarak görev yapmaları halinde öğrencilerine eleştirel düşünmeyi 
kazandırmaları, önlem alınmadığı takdirde, mümkün görünmemektedir.

Literatürdeki bazı çalışmalar Türkiye'de öğrencilerin eleştirel düşünmeye ve bu özelliği kullanmayı gerektiren durumlara maruz kalmadıklarını işaret etmektedir (Yalçınkaya, 2016). Bu olgunun ise eleştirel düşünmeye engel olduğu düşünülmektedir. Bununla birlikte Türkiye'de düşünmenin genel anlamda baskılanması, eğitim yaşantıları boyunca süregelen ezberci yaklaşım, merkezi sınavların ezberci yaklaşımı teşvik etmesi, yenilikçi olmayan, öğrenciyi merkeze almayan, düşünme firsatı vermeyen, işbirliğine yöneltmeyen, fikirlerin ifade edilmesine imkân tanımayan öğretim yöntem ve teknikleri ile sonuç odaklı değerlendirme etkinlikleri gibi faktörlerin eleştirel düşünmeye engel teşkil ettiği düşünülmektedir. Eleştirel düşünme becerileri üst düzey düşünme etkinlikleri gerektirir. Öğretmenler tarafından sıklıkla tercih edilen düz anlatım, üst düzey bilişsel becerilerin kullanılmasına uygun bir zemin hazırlayamaz. Zaman ve kaynak eksikliklerine bağlı sorunlar nedeniyle tercih edilen düz anlatım yöntemi, ezbere dönük olması hesaba katıldığında, öğrencilerin eleştirel düşünme becerilerini kullanmalarına engel olmaktadır. Yine sinavlarda Bloom Taksonomisine göre çoğunluklar bilgi ve kavrama basamaklarında yer alan soruların öğrenciye yöneltilmesi öğrencinin üst düzey bilişsel beceriler kullanmasının önüne geçmektedir. Bu nedenle öğrenci süreç içinde de, değerlendirme aşamasında da üst düzey bilişsel becerileri kullanmamaktadır. Anılan nedenlerin öğretmen adaylarının eleştirel düşünme düzeylerinin yetersizliği üzerinde rol oynadığ 1 araştırmacı tarafından düşünülmektedir.

Bugün Türkiye'de toplumsal hayatta hemen hemen her gün görülen birçok olay ve olgu toplumsal düzlemde eleştirel düşünme yetersizliğini akla getirmektedir. Eski nüfus cüzdanlarının yerine almakta olan yeni kimlik kartlarının dağıtımının 2017 yılında biteceği ve belirtilen tarih itibarıyla yeni kimliklerini teslim almayanların cezai işleme tabii tutulacağı söylentisinin binlerce insanın nüfus müdürlüklerine akın etmesine sebep olması bu yetersizliğin yakın zamanlı bir örneğidir (www.bursa.com, 2017). Bunun sonucunda nüfus müdürlükleri rutin görevlerini yapmakta zorlanmış, bu söylentiye inanan insanlar ise günlerce nüfus müdürlükleri kapılarında sıra bekleyerek mağdur olmuştur. Temeli olmayan, doğrulanmış bir bilgiye dayanmayan ve nerden yayıldığı dahi bilinmeyen bu söylenti binlerce insanın sorgulamadan doğru kabul ettiği bir olguya dönüşmüştür. $\mathrm{Bu}$ bilgiyi duyan insanlar, bahse konu bilginin ne kaynağını ne de güvenilirliğini sorgulamıştır. Basit bir düşünme etkinliği ile doğru olmadığı kolayca anlaşılabilecek bir olgu, resmi bir kurumun işleyişini bozmuştur. Binlerce insanın böylesi basit söylentileri dahi sorgulamadan kabul etmesi Türkiye Cumhuriyeti vatandaşlarının amaçlı ve iyi planlanan propagandalara açık bir yapıda olduğunu düşündürmektedir. Eleştirel düşünme karşılaşılan bilginin incelenmesine ve değerlendirilmesine yönelik bir süreçtir. Bu yönüyle medya okuryazarlığı ile de yakından ilişkilidir. Bu olguya yönelik olarak Kurt ve Kürüm (2010), eleştirel düşünen kişilerin bilgileri detaylı bir şekilde ele alarak etkili ve amaca dönük kullandıklarını, bilgiye ulaşmak için alternatiflere yöneldiklerini, bilgileri doğrulama çabası içinde olduklarını ve şüphelerine yönelik kanıt aradıklarını belirtmişlerdir. Benzer olarak Nalçacı, Meral ve Şahin (2016), eleştirel düşünmenin medya okuryazarlığını pozitif yönde etkilediğini iddia etmiş, eleştirel düşünürlerin medyada maruz kaldığ1 bilgiler karşısında olay ya da durumun özünü anlamaya yönelik sorgulamalar yaptığına dikkat çekmiştir. Karşılaştığı bilgilere şüphe ile yaklaşan eleştirel düşünür medyanın kitleleri etkileme gücünün farkındadır. Eleştirel düşünemeyen toplum, Türkiye'yi hem yukarıda bahsi geçen tehditlere karşı savunmasız bırakmakta hem de modern dünya ile rekabet gücünü zayıflatmaktadır.

2017 yılında Türkiye'de açığa çıkan bir olay eleştirel düşünme sorunlarını çok açık bir şekilde gözler önüne sermektedir. Bir nevi saadet zinciri olarak nitelendirilebilecek olan Çiftlik Bank adındaki oluşuma yaklaşık 79.000 kişi 511,7 milyon TL yatırmış ve sistemin çökmesi sonucu on binlerce kişi mağdur olmuştur (www.haberturk.com, 2017). Sisteme para yatıran vatandaşlar sistemin herhangi bir üretim faaliyetine dayanıp dayanmadığını sorgulamadan hareket etmişlerdir. Sadece yüksek kar vaadi karşısında on binlerce insanın, konu üzerinde hiç düşünmeden yüksek miktarlarda para yatırması Türkiye açısından korkutucu bir durumdur. Kişiler bilgi toplamaya ihtiyaç duymamış, iddiaların ve argümanların doğruluğunu analiz etmemişlerdir. $\mathrm{Bu}$ durum Türkiye'nin düşünme problemlerini net bir şekilde gözler önüne sermektedir.

Türkiye'de eleştirel düşünme sorunlarına sadece sıradan vatandaşlar ve öğrencilerde değil, toplumun tüm kesimlerinde rastlamak mümkündür. Eleştirel düşünmenin beceriler ve eğilimlerden ibaret, iki boyutlu bir yapısı olduğu birçok araştırmacı tarafindan belirtilmektedir (Cottrell, 2005; Facione, 2000; Halpern, 2002; Norris, 1985) . Yine eleştirel düşünmenin kuramsal temellerini oluşturmak üzere yapılmış bir uzlaşı çalışması olan Delphi Projesinde eleştirel düşünme becerilerinin, eleştirel düşünme eğilimleri sayesinde kullanılabileceği belirtilmiştir (Facione, 2015). Diğer taraftan eleştirel düşünmenin hayata geçirilmesi kavramlara yönelik doğru bir anlayış ile mümkün olabilir. Değerlendirilen olay, olgu ya da konuya yönelik kavramların yanlış yapılandırılmış olması veya düşünen kişinin kavram yanılgılarına sahip olması, elde edilecek sonuçların hatalı olmasına neden olacaktır. Türkiye'de eleştirel düşünmeyi konu edinen akademik çalışmaların azımsanamayacak bir bölümünde eleştirel düşünme becerileri ve eğilimleri arasındaki farka dikkat edilmediği ve bu kavramların sıklıkla birbirlerinin yerine kullanıldığı görülmektedir. $\mathrm{Bu}$ çalışmalarda, kullanılan eleştirel düşünme tutum ve eğilim ölçekleri ile veri toplayan araştırmacılar çalışmalarının sonuç ve tartışma bölümlerinde doğrudan eleştirel düşünme becerilerine ya da düzeylerine yönelik çıkarımlarda ve yargılarda bulunmuşlardır. Eleştirel düşünme eğilimi olmayan bir bireyin eleştirel düşünme becerilerini kullanmayacağı varsayılabilir ancak söz konusu kişinin bu becerilere sahip olduğunu ya da olmadığını iddia edebilmek ancak bu becerilerin ölçülmesi ile mümkün olabilir. $\mathrm{Bu}$ bilgiler 1şığında Türkiye'nin eğitim alanında en alt kademeden en üst kademeye kadar kapsamlı bir eleştirel düşünme planına ihtiyacı olduğunu söylenebilir. 
Alanyazında yer alan birçok çalışma eleştirel düşünmenin, bu amaca dönük uygulamalar ve öğretim etkinlikleri ile geliştirilebileceğini öne sürmektedir. Schreglmann ve Karakuş (2017)'a göre eleştirel düşünmeyi geliştirmek için eleştirel düşünmeye uygun uygulamalar geliştirmek gereklidir. Eğmir ve Ocak (2017) ise çalışmalarında eleştirel düşünmeye yönelik hazırlanan öğretimin eleştirel düşünme düzeylerini anlamlı derecede ve olumlu yönde etkilediğini belirlemiştir. Reed ve Kromrey (2001), Paul tarafından geliştirilen eleştirel düşünme modelini deneysel çalışmalarında uygulamış ve deney grubunun eleştirel düşünmeye yönelik öğretim sonucunda eleştirel düşünme düzeylerinde anlamlı düzeyde yükselme olduğunu belirtmişlerdir. İbrahimoğlu ve Öztürk (2013), sosyal bilgiler dersinde örnek olay kullanımının öğrencilerin eleştirel düşünme düzeylerine etkisini incelemiş ve örnek olay kullanımının eleştirel düşünme üzerinde anlamlı bir farklılık oluşturduğunu tespit etmişlerdir. Eleştirel düşünmeye yönelik yöntemler kullanarak başka araştırmacılar da eleştirel düşünme üzerinde anlamlı gelişimler tespit etmişlerdir (Yang, 2012; Bodur, 2010; Narin ve Aybek, 2010; Tok ve Sevinç, 2010; Bessick, 2008; Aybek, 2007; Kurnaz, 2007). Sayılan bu çalışmaların sonuçları, araştırma bulguları ile paraleldir. Bu çalışmada tartışmalı konuların eleştirel düşünme üzerindeki etkisini incelemek üzere müdahale sürecinde tartışmalı konular Richard Paul modeli aracılığı ile eleştirel düşünme öğretimine uygun olarak Türkiye Cumhuriyeti Tarihi - I dersi kapsamında ele alınmış ve öğretmen adaylarının eleştirel düşünme düzeylerinde olumlu yönde anlamlı bir gelişim elde edilmiştir $(p=0,013)$. Kontrol grubunda ise anlamlı farklılığa rastlanılmamıştır $(\mathrm{p}=0,400)$. Bu verilere dayanarak tartışmalı konulara eleştirel düşünme öğretimi kapsamında derslerde yer verilmesinin eleştirel düşünmeyi olumlu yönde etkilediği söylenebilir. Yöntemin etkili olmasında öğretmen adaylarının süreç boyunca aktif olmalarının etkisi olabilir. Eleştirel düşünme aktif katılımı gerektirir (Snyder ve Snyder, 2008). Browne ve Freeman (2000), aktif öğrenmeye dayalı bir tasarımının eleştirel düşünmeye olanak sağladığını öne sürmüşlerdir. Güzel (2005)'e göre tarih konuları eleştirel düşünme öğretimi için elverişlidir. Yine Güzel, eleştirel düşünme becerilerine yönelik öğretimin akademik başarı, sosyal bilgilere yönelik tutum ve eleştirel düşünme düzeylerinde anlamlı bir gelişime neden olduğunu tespit etmiştir. Ayrıca bu şekilde yürütülen dersler, eleştirel düşünmenin kalıcı olmasını da sağlamıştır. Bu kapsamda eleştirel düşünmeye yönelik öğretim verilen öğrencilerin, eleştirel düşünme eğilimleri de istenilen düzeye çıkarılabilirse, hayatlarının her anında eleştirel düşünmeyi kullanacakları söylenebilir. Anılan nedenlerle eleştirel düşünme öğretiminin mevcut dersler kapsamında dahi uygulanmasının anlamlı gelişimlere neden olabileceği sonucuna ulaşılmıştır.

Bu çalışmada tartışmalı konuların derste ele alınması süreci Richard Paul tarafindan geliştirilen modele uygun olarak yürütülmüştür. Reed ve Kromrey (2001), Paul tarafindan geliştirilen eleştirel düşünme modelini deneysel çalışmalarında uygulamış ve deney grubunun eleştirel düşünmeye yönelik öğretim sonucunda eleştirel düşünme düzeylerinde anlamlı düzeyde yükselme olduğunu belirtmişlerdir. $\mathrm{Bu}$ çalışmada deney grubunun kaydettiği anlamlı düzeydeki ilerleme de bu bulguyu destekler niteliktedir. Başka bir çalışmasında Reed (1998), aynı modeli tarih dersinde eleştirel düşünmeyi desteklemek üzere kullandığında öğrencilerin eleştirel düşünme becerilerinin tek bir dersle dahi geliştirilebildiği bulgusuna ulaşmıștır. Scanlan doktora tezinde (2006), Richard Paul'un modelini esas alarak yürüttüğü Retorik ve Kompozisyon dersi sonucunda öğrencilerin yazmayı netleştirme, argüman analizi, destekleyici bilgilerin kullanımı, organizasyon ve gramer alanları ile eleştirel düşünme becerilerinde gelișim gösterdiklerini belirtmiştir. Bu bulgular, eleştirel düşünmeyi destekleme konusunda bu araştırmada kullanılan modelin etkili olduğunu göstermektedir. Söz konusu modelin tartışmalı konulara derste yer verilmesi esnasında kullanılmış olması ve netice itibarıyla deney grubunda yer alan öğretmen adaylarının eleştirel düşünme düzeylerinde anlamlı düzeyde farklılık görülmesi dikkate alındığında bahsi geçen çalışmaların sonuçları ile bu çalışma uyumludur.

Tartışmalı konular gibi unsurların derslerde öğrencilerce tartışılmasının eleştirel düşünmeye olan olumlu ve anlamlı etkisini destekler nitelikte literatürde birçok çalışma bulunmaktadır (Cantürk-Günhan ve Başer, 2009; Dolapçıŏlu, 2015; Gültepe, 2011; Narin ve Aybek, 2010; Savich, 2008; Sevgi ve Şahin, 2017; Uysal, 1998; Yang, 2008; Yıldızbaş, 2017). Sevgi ve Şahin (2017), çalışmalarında gazete haberlerinin sınıf içinde tartışılmasının eleştirel düşünmeyi anlamlı düzeyde geliştirdiğini tespit etmişlerdir. Çalışmamızın sonuçları ile uyumlu olan bu bulgu aslında eleştirel düşünmenin Delphi projesi sonucunda üzerinde uzlaşı sağlanan altı beceri boyutunu uyarmanın bir sonucu olarak ortaya çıkmıştır. Çünkü tartışma ilkelerine uygun yürütülen bir tartışma kanıt, argüman ve iddialara yönelik yorumlama, analiz etme, değerlendirme, çıkarımda bulunma, öz düzenleme ve açıklama becerileri gerektirir. Cantürk-Günhan ve Başer (2009), probleme dayalı öğrenmenin eleştirel düşünmeyi anlamlı düzeyde desteklediğini belirtmişlerdir. Bu bulgu da araştırmamız sonuçları ile paraleldir. Probleme dayalı öğretimin amacı öğrencileri gerçek hayat problemleri ile yüz yüze getirmek ve onları araştırma, sorgulama ve tartışma faaliyetlerine yönlendirmektir. $\mathrm{Bu}$ yönüyle tartışmalı konularla elde edilebilecek kazanımlar probleme dayalı öğretime benzerdir. Yang (2008) ise, Sokratik sorgulamanın eleştirel düşünme düzeylerine etkisini incelediği çalışmasında bu yöntemin eleştirel düşünmeyi anlamlı derecede desteklediğini tespit etmiş, bu sonucu öğrencilerin fikir alışverişinde bulunmalarına ve kendi anlayışlarını değerlendirmelerine bağlamıştır. Savich (2008) benzer olarak etkileşimli ya da sorgulamaya dayalı öğretimin eleştirel düşünmenin gelişiminde anlamlı etkileri olduğunu tespit etmiştir. Tartışmalı konular gibi sınıf içi tartışmalar içeren yöntemlerin eleştirel düşünme üzerinde olumlu etkisinin nedenleri arasında en başta, öğrencinin öğrenme sürecine aktif olarak katılımı gelmektedir. Öğrenciyi aktif kılan yöntemler derse yönelik tutumu olumlu yönde etkilemektedir (İbrahimoğlu ve Öztürk, 2013). Hem katılımı hem de derse yönelik tutum ve motivasyonu üst seviyelerde olan öğrencilerin ders kazanımlarına daha kolay ulaşmaları beklenen bir durumdur. Bu kapsamda öğrenciyi aktif kılan tartışmalara ve tartışmalı konulara derste yer verilmesinin, eleştirel düşünme becerilerinin gelişimine hizmet edeceği açıktır. 


\subsection{Sonuç}

Araştırma sürecinde aşağıdaki sonuçlara ulaşılmıştır:

Sosyal bilgiler öğretmen adayları eleştirel düşünmemektedir.

Öğretmen adaylarının, öğretmenlik mesleğini icra ettikleri takdirde öğrencilerine eleştirel düşünmeyi kazandırmaları mümkün görünmemektedir.

Tartışmalı konuları içerecek şekilde düzenlenecek dersler, eleştirel düşünme modellerine uygun yürütüldügüü takdirde öğretmen adaylarının eleştirel düşünme becerilerini olumlu yönde etkileyebilir.

\section{3. Öneriler}

Bulguların analiz edilmesinin ve literatürle birlikte değerlendirilmesinin ardından aşağıdaki önerilerin olumlu etkileri olabileceği düşünülmüştür:

(i) Araştırmada lisans düzeyinde Türkiye Cumhuriyeti Tarihi - I dersinde tartışmalı konuların ele alınmasının eleştirel düşünebilme firsatları yarattığ anlaşılmıştır. Eleştirel düşünme becerileri, tesadüfi ve küçük gelişmeler yok sayıldığında, ancak planlı etkinlikler aracılığıyla geliştirilebilir.Bu bağlamda lisans düzeyinde sosyal bilgiler eğitimi alan dersleri ile tarih temelli derslerde tartışmalı konuların derslere dahil edilebilmesi için ilgili derslerin programlarında düzenlemeler yapılabilir.

(ii) Araştırmada tartışmalı konuların, bir eleştirel düşünme modeli aracılığı ile ele alınmasının öğretmen adaylarının eleştirel düşünme düzeylerine olumlu yönde etki ettiği anlaşılmıştır. Araştırmacılar bu olumlu etkinin, tartışmalı konuların planlı bir modelle ele alınmasından kaynaklandığını düşünmektedir. $\mathrm{Bu}$ nedenle çalışmada kullanılan eleştirel düşünme modeli, farklı derslere uyarlanarak etkisi değerlendirilebilir.

(iii) Tartışmalı konuların ele alınmasının, eleştirel düşünme düzeyiyle birlikte eleştirel düşünme eğilimlerine etkisi incelenebilir.

\section{Kaynakça}

Acun, İ., Demir, M. \& Göz, N. L. (2010). Öğretmen adaylarının vatandaşlık yeterlilikleri ile eleştirel düşünme becerileri arasındaki ilişki. Sosyal Bilgiler Eğitimi Araştırmaları Dergisi, 1(1), 107-123.

Akar, C. (2007). İlköğretim öğrencilerinde eleştirel düşünme becerileri (Yayınlanmamış Doktora Tezi). Gazi Üniversitesi, Ankara.

Avaroğulları, M. (2015). Sosyal bilgiler öğretiminde tartışmalı konularla ilgili bir eylem araştırması. Education Sciences, 9(6), 139-150.

Aybek, B. (2007). Konu ve beceri temelli eleştirel düşünme öğretiminin öğretmen adaylarının eleştirel düşünme eğilimi ve düzeyine etkisi. Çukurova Üniversitesi Sosyal Bilimler Enstitüsü Dergisi, 16(2), 43-60.
Baker, M., Rudd, R. \& Pomeroy, C. (2001). Relationships between critical and creative thinking. Journal of Southern Agricultural Education Research, 51(1), 173188.

Bessick, S. C. (2008). Improved critical thinking skills as a result of direct instruction and their relationship to academic achievement(Yayımlanmamış Doktora Tezi). Indiana University of Pennsylvania, Pennsylvania.

Bodur, H. (2010). İlkögrretim ikinci sınıf hayat bilgisi dersinde içerik temelli eleştirel düşünme ögretiminin ögrencilerin eleştirel düşünme becerilerine etkisi. (Yayımlanmamış Yüksek Lisans Tezi).Selçuk Üniversitesi, Konya.

Browne, M. N. \& Freeman, K. (2000). Distinguishing features of critical thinking classrooms. Teaching in Higher Education, 5(3), 301-309.

Büyüköztürk, Ş., K1lıç Çakmak, E., Akgün, Ö. E., Karadeniz, Ş. \& Demirel, F. (2012). Bilimsel araştırma yöntemleri. Ankara: Pegem Akademi.

Byford, J., Lennon, S. \& Russell, W. B. (2009). Teaching controversial issues in the social studies: A research study of high school teachers. The Clearing House: A Journal of Educational Strategies, Issues and Ideas, 82(4), 165-170.

Cantürk-Günhan, B., \& Başer, N. (2009). Probleme dayalı öğrenmenin öğrencilerin eleştirel düşünme becerilerine etkisi. Journal of Turkish Educational Sciences, 7(2), 451-482.

Cottrell, S. (2005). Critical thinking skills: Developing effective analysis and argument. Londra: Palgrave Macmillan.

Creswell, J. W. (2013). Araştırma deseni: Nicel, nitel ve karma yöntem yaklaşımları (S. B. Demir, Çev. Ed.). Ankara: Eğiten Kitap.

Dolapçıŏlu, S. D. (2015). Matematik dersinde otantik ögrrenme yoluyla eleştirel düşünme becerisinin geliştirilmesi: Bir eylem araştırması(Yayımlanmamış Doktora Tezi). Çukurova Üniversitesi, Adana.

Durr, C. R., Lahart, T. E. \& Maas, R. M. (1999). Improving critical thinking skills in secondary math and social studies classes. (Yüksek Lisans Eylem Araştırması Projesi, ERIC Document Reproduction Service No. ED434016). Saint Xavier University, Chicago.

Eğmir, E., \& Ocak, G. (2017). Eleştirel düşünme öğretim programının öğrencilerin eleştirel düşünme becerisi ve özdeğerlendirme düzeylerine etkisi. Karaelmas Ĕ̆itim Bilimleri Dergisi, 5(1), 138-156.

Ennis, R. H. (1985). Goals for a critical thinking curriculum. Developing minds: A resource book for teaching thinking içinde (s. 54-58). Virginia: Association for Supervision and Curriculum Development.

Epstein, R. L. \& Kernberger, C. (2006). Critical thinking. Australia: Thomson/Wadsworth. 
Ersoy, A. F. (2013). Sosyal bilgiler öğretmen adaylarının tartışmalı konulara katılımını etkileyen etmenler. Sosyal Bilgiler Eğitimi Araştırmaları Dergisi, 4(1), 24-48.

Facione, P. A. \&Facione, N.C. (1994). The California Academic Press https://www.insightassessment.com/ Resources/Teaching-Training-and-Learning-Tools/ Holistic-Critical-Thinking-Scoring-Rubric-HCTSR adresinden 10.05.2017 tarihinde erișildi.

Facione, P. A., Sanchez, C. A., Facione, N. C., \& Gainen, J. (1995). The disposition toward critical thinking. The Journal of General Education, 44(1), 1-25.

Facione, N. C. \& Facione, P. A. (1996). Externalizing the critical thinking in knowledge development and clinical judgment. Nursing Outlook, 44(3), 129-136.

Facione, P. A. (2000). The disposition toward critical thinking: Its character, measurement, and relationship to critical thinking skill. Informal Logic, 20(1), 61-84.

Facione, P. A. (2015). Critical thinking: What it is and why it counts. https://www.insightassessment.com/Resources /Importance-of-Critical-Thinking/Critical-ThinkingWhat-It-Is-and-Why-It-Counts/Critical-Thinking-WhatIt-Is-and-Why-It-Counts-PDF adresinden 10.09.2017 tarihinde erişildi.

Gültepe, N. (2011). Bilimsel tartışma odaklı öğretimin lise öğrencilerinin bilimsel süreç ve eleştirel düşünme becerilerinin geliştirilmesine etkisi(Yayınlanmamış Doktora Tezi). Gazi Üniversitesi, Ankara.

Gülveren, H. (2007). Eğitim fakültesi öğrencilerinin eleştirel düşünme becerileri ve bu becerileri etkileyen eleştirel düşünme faktörleri(Yayımlanmamış Doktora Tezi). Dokuz Eylül Üniversitesi, İzmir.

Güzel, S. (2005). Eleştirel Düşünme Becerilerini Temele Alan İlkögretim 4. Sinıf Sosyal Bilgiler Öğretiminin Öğrenme Ürünlerine Etkisi(Yayınlanmamış Yüksek Lisans Tezi). Mustafa Kemal Üniversitesi, Hatay.

Halpern, D. F. (2002). Thought and knowledge: An introduction to critical thinking. Londra: Routledge.

İbrahimoğlu, Z.,\& Öztürk, C. (2013). Sosyal bilgiler dersinden örnek olay yöntemi kullanımının öğrencilerin akademik başarı derse karşı tutum ve eleştirel düşünme becerileri üzerine etkileri. Uludă̆ Üniversitesi Ĕ̆itim Fakültesi Dergisi, 26(2), 523-548.

Kurnaz, A. (2007). Illköğretim beşinci sınıf sosyal bilgiler dersinde beceri ve içerik temelli eleştirel düşünme ögretiminin öğrencilerin eleştirel düşünme becerileri, erişi ve tutumlarına etkisi(Yayımlanmamış Doktora Tezi). Selçuk Üniversitesi, Konya.

Kurt, A. A., \& Kürüm, D. (2010). Medya okuryazarlığı ve eleştirel düşünme arasındaki ilişki: Kavramsal bir bakış. Mehmet Akif Ersoy Üniversitesi Sosyal Bilimler Enstitüsü Dergisi, 2(2), 20-34.

Nalçacı, A., Meral, E., \&Şahin, İ. F. (2016). Sosyal bilgiler öğretmen adaylarının eleştirel düşünme ile medya okuryazarlıkları arasındaki ilişki. Doğu Coğrafya Dergisi, 21(36), 1-12.
Narin, N. \& Aybek, B. (2010). İlköğretim ikinci kademe sosyal bilgiler öğretmenlerinin eleştirel düşünme becerilerinin incelenmesi. Çukurova Üniversitesi Sosyal Bilimler Enstitüsü Dergisi, 19(1), 336-350.

Norris, S. P. (1985). Synthesis of research on critical thinking. Educational Leadership, 42(8), 40-45.

Öztürk, N., \&Ulusoy, H. (2008). Lisans ve yüksek lisans hemşirelik öğrencilerinin eleştirel düşünme düzeyleri ve eleştirel düşünmeyi etkileyen faktörler. Maltepe Üniversitesi Hemşirelik Bilim ve Sanatı Dergisi, 1(1), 15-25.

Parker, W. C. (2012). Social studies in elementary education. Boston: Pearson Education.

Paul, R., \&Elder, L. (2002). Critical thinking: Tools for taking charge of your professional and personal life. New Jersey: Financial Times Prentice Hall.

Reed, J. H. (1998). Effect of a model for critical thinking on student achievement in primary source document analysis and interpretation, argumentative reasoning, critical thinking dispositions, and history content in a community college history course (Yayımlanmamış Doktora Tezi). University of South Florida, Florida.

Reed, J. H. \& Kromrey, J. D. (2001). Teaching critical thinking in a community college history course: Empirical evidence from infusing Paul's model. College Student Journal, 35(2), 201-201.

Savich, C. (2008). Improving critical thinking skills in history. Oakland University. Education Resources Information Center. ERIC No: ED501311.

Scanlan, J. S. (2006). The effect of Richard Paul's universal elements and standards of reasoning on twelfth grade composition(Yayımlanmamış Doktora Tezi).Alliant International University, California.

Schreglmann, S., \& Karakuş, M. (2017). Eğitsel arayüz destekli eğitim yazılımlarının eleştirel düşünme ve akademik başarı üzerindeki etkisi. Mersin Üniversitesi Ĕgitim Fakültesi Dergisi, 13(3), 839-855.

Sevgi, Y. \& Şahin, F. (2017). Gazete haberlerindeki sosyobilimsel konuların argümantasyon yöntemiyle tartışılmasının 7. sınıf öğrencilerinin eleştirel düşünme becerileri üzerine etkisi. Journal of Human Sciences, 14(1), 156-170.

Suryanto, I. E. (2015). Analysis of the Reasons of Teaching Controversial Issues on Public Policy to the Senior High School Students. Journal of Education and Practice, 6(36), 56-60.

Snyder, L. G. \& Snyder, M. J. (2008). Teaching critical thinking and problem solving skills. The Journal of Research in Business Education, 50(2), 90-99.

Tok, E., \&Sevinç, M. (2010). Düşünme becerileri eğitiminin eleştirel düşünme ve problem çözme becerilerine etkisi. Pamukkale Üniversitesi Ĕ̆itim Fakültesi Dergisi, 27(27), 67-82.

Uysal, A. (1998). Sosyal Bilimler ögretim yöntemlerinin eleştirici düşünme gücünün gelişmesindeki rolü 
(Yayımlanmamış yüksek lisans tezi). İnönü Üniversitesi, Malatya.

Yalçınkaya, T. (2016). Sözdebilim temalı bilimin doğası ögretiminin fen bilgisi ögretmen adaylarının sözdebilim algılarına ve eleştirel düşünme becerilerine etkisi.(Yayımlanmamış Doktora Tezi). Mersin Üniversitesi, Mersin.

Yang, Y. T. C. (2012). Cultivating critical thinkers: Exploring transfer of learning from pre-service teacher training to classroom practice. Teaching and Teacher Education, 28(8), 1116-1130.

Yang, Y. T. C. (2008). A catalyst for teaching critical thinking in a large university class in Taiwan: Asynchronous online discussions with the facilitation of teaching assistants. Educational Technology Research \& Development, 56(3), 241-264.

Yıldızbaş, H. (2017). Ortak bilgi yapılandırma modeline dayalı ögretimin öğrencilerin akademik başarılarına ve eleştirel düşünme becerilerine etkisi(Yayımlanmamış Yüksek Lisans Tezi). Necmettin Erbakan Üniversitesi, Konya.

www.bursa.com (2017) http://www.bursa.com/dedikodunufus-mudurluklerinde-yogunluga-neden-oldun319923/ adresinden 20.02.2018 tarihinde erişildi.

www.haberturk.com (2017) http://www.haberturk.com/6soruda-ciftlik-bank-on-binlerce-kisi-nasil-dolandirildi1878297 adresinden 19.03.2018 tarihinde erişildi. 
